\title{
Domestication and Length-Weight Relationship of Striped Snakehead Channa striata (Bloch)
}

\author{
Samliok Ndobe ${ }^{1}$, Novalina Serdiati ${ }^{1}$ and Abigail Moore ${ }^{2}$ \\ ${ }^{1}$ Aquaculture Study Program, Faculty of Animal Husbandry and Fisheries, Tadulako University, Palu, Indonesia \\ Email: samndobe@yahoo.com \\ ${ }^{2}$ Institute of Fisheries and Marine Science (STPL), Palu, Indonesia \\ Email: abigail2105@yahoo.com
}

\begin{abstract}
Samliok Ndobe, Novalina Serdiati and Abigail Moore. 2014. Domestication and Length-Weight Relationship of Striped Snakehead Channa striata (Bloch). International Conference of Aquaculture Indonesia 2014. The striped snakehead Channa striata is a freshwater fish with potential for aquaculture for consumption and as a source of nutraceutical products. A domestication program using seed (wild fry) from Sigi District in Central Sulawesi Province was initiated in 2013 to promote snakehead culture (grow-out and full-cycle) in this province. During the first two stages (fry to fingerling, fingerling to juvenile), cannibalism was the only observed cause of mortality. The main aim of the third stage was to evaluate locally available natural feeds for juvenile snakeheads over $180 \mathrm{~mm}$ in total length. Juvenile snakeheads were reared for 8 weeks in individual compartments in a concrete tank with 3 natural feed treatments (A: Golden apple snail, Pomacea canaliculata; B: Blue panchax, Aplocheilus panchax; C: Earth worms, Lumbricus rubellus) and 5 replicates per treatment. Feeding (11\% of body weight) was twice daily. All juveniles remained in good health, however results showed that treatment B produced the highest relative growth in wet weight $(21.8 \%)$, significantly different from A $(11.8 \%)$ and $\mathrm{C}(9.5 \%)$. Over the 3-stage study period the length-weight relationship $\mathrm{W}=a \mathrm{~L}^{b}$ was isometric $(b=3)$, with considerable variation in individual growth patterns.
\end{abstract}

Keywords: Channa striata; Domestication; Natural feed; Length-weight relationship

\section{Introduction}

Freshwater aquaculture is increasingly important in the context of food security and sustainable development, as a source of high quality protein and income for rural communities (Hambrey et al., 2008). There is also a growing interest in natural remedies and foods with health benefits or nutraceuticals (Keservani et al., 2010). Indonesia is widely recognised as a biodiversity hotspot, with many native freshwater fish species however freshwater aquaculture development has been focused mainly on introduced species. One native species with high potential for aquaculture both as a food fish (Srivastava et al., 2011) and as a source of albumin and other products with recognised health benefits (Laila et al., 2011; Mustafa et al., 2012; Shafri and Manan, 2012) is the striped snakehead, Channa striata, known locally as ikan gabus. In Central Sulawesi, wild $C$. striata populations and their habitats are under heavy pressure and declining, increasing the urgency of domestication (Ndobe et al., 2013).

Domestication was initiated as part of a research programme to promote sustainable snakehead use and management in Central Sulawesi. Long term aims include the development of captive breeding and post-harvest processing. The identification of suitable feed for captive reared fish at all stages of the life cycle is an important aspect of the long and complex process of domestication, as pointed out by Liao and Huang (2000). In the wild, Channa striata are wellknown as voracious predators; what little data are available in FishBase indicate a varied diet of benthic organisms and nekton, including fish, invertebrates (insects, worms, molluscs, crustaceans), and even frogs (Froese and Pauly, 2013). However, like Kumar et al. (2008) we found that "little is known about their food preferences", in the wild or in captivity.

In the first stage, fry from Sigi District (total length TL \pm SD: $43.9 \pm 3.3 \mathrm{~mm}$ ) were reared to the fingerling stage using 3 feed treatments: mosquito larvae, artificial (pelleted) feed and a mixture of the two (Ndobe et al., 2013). Though mosquito larvae were adequate for fry and small fingerlings (to $\mathrm{TL} \approx 60 \mathrm{~mm}$ ), the combined feed gave the best results, while with pelleted feed 
alone mortality was high with low average growth. Higher mortality (including cannibalism) and lower growth in $C$. striata fry and fingerlings fed on pelleted feed compared to those given live or fresh feed has also been reported by other studies (Ebanasah and Jayaphakas, 1994; Sarowar et al., 2010). However the results of Ndobe et al. (2013) indicate that for C. striata fry and fingerlings, combining natural and artificial (pelleted) feeds may be beneficial, and that further research should aim to develop a range of suitable live or fresh feeds as well as artificial feeds, and determine optimal strategies for using a variety of combinations under specific culture conditions, including potential feed availability.

During the second stage, the fingerlings were successfully reared to juvenile size ( $\mathrm{TL} \pm \mathrm{SD}=$ $178.5 \pm 7.0 \mathrm{~mm}$ ) using a live feed readily available locally at low cost. This was the small fish blue panchax Aplocheilus panchax, locally known as kepala timah (Serdiati et al., 2013). Based on the results from this phase, we consider further research is required into live feed culture, separately or in a polyculture system with $C$. striata juveniles. During both phases, all mortality observed was due to cannibalism, occurring when differential growth rates led to substantial size differences between individuals, leading us to conclude that successful grow-out of wild $C$. striata fry requires frequent sizebased sorting.

The specific aim of the third stage presented in this paper was to evaluate the suitability and relative performance of three live or natural (fresh) feeds for the grow-out of large (SL $\geq 18 \mathrm{~cm}$ ) C. striata juveniles: the blue panchax Aplocheilus panchax used in stage two, and two other locally available high protein feeds. Length-weight data is generally considered an important characteristic of fish species and stocks (Schneider et al., 2000). We therefore also calculated the length-weight relationship for the striped snakehead juveniles from capture as fry to the end of this third stage.

\section{Materials and Methods}

\section{Materials and Layout}

Fifteen healthy juvenile Channa striata $(\mathrm{TL} \pm \mathrm{SD}=19.8 \pm 0.8 \mathrm{~cm} ; \mathrm{W} \pm \mathrm{SD}=71.9 \pm 1.5 \mathrm{~g})$ were selected from the fish reared in stages one and two. The culture environment was a concrete pond approximately $160 \mathrm{~cm}$ x $400 \mathrm{~cm}$. Fifteen mesh netting compartments $(50$ wide x 75 long x $100 \mathrm{~cm}$ deep) were suspended in the pond, with the base resting on the pond substrate. One snakehead juvenile was placed in each net compartment, thus avoiding cannibalism. Water depth was $50 \mathrm{~cm}$ and water quality was maintained through daily removal of organic matter (uneaten food, faeces, etcetera) from the nets and pond, and partial exchange of the water in the pond. Condition and behaviour of the fish were monitored daily, including feeding behaviour and survival.

Three local live or fresh feed treatments were used, with five replicates (each consisting of one fish in one net) per treatment. In treatment A (golden apple snails, Pomacea canaliculata, collected from irrigated paddy fields where they are a pest), the snails were de-shelled and the entire body was chopped up. In treatment B (blue panchax, Aplocheilus panchax, caught with small scoop nets in stormwater drainage ditches), the prey fish were released alive into the net compartment. In treatment $\mathrm{C}$ (earthworms, Lumbricus rubellus, obtained from a worm composting program), the worms were fed live (whole) or freshly chopped, depending on size. The nutritional composition of each feed is given in Table 1. For blue panchax (treatment B) nutritional content was determined through proximate analysis in the laboratory; for treatment A (golden apple snails) and $\mathrm{C}$ (earthworms), proximate analysis values were derived from the scientific literature.

Table 1. The three live feed treatments used

\begin{tabular}{|c|c|c|c|c|c|c|c|}
\hline \multirow{2}{*}{ Code } & \multirow{2}{*}{$\begin{array}{c}\text { Common Name } \\
\text { English/Indonesia }\end{array}$} & \multirow{2}{*}{ Latin Name } & \multicolumn{5}{|c|}{ Approximate composition (dry weight) in \% } \\
\hline & & & Protein & Fat & Ash & Other & Reference \\
\hline A & $\begin{array}{l}\text { Golden apple } \\
\text { snail }\end{array}$ & Pomacea canaliculata & 66 & 3 & 13 & 18 & Thongprajukaew et al. (2013) \\
\hline B & Blue panchax & Aplocheilus panchax & 62 & 19 & 7 & 12 & UNTAD Laboratory $2013^{1}$ \\
\hline $\mathrm{C}$ & Earth worms & Lumbricus rubellus & 69 & no data ${ }^{2}$ & 7 & 24 & Istiqomah et al. (2009) \\
\hline
\end{tabular}

${ }^{1}$ Analysis of a sample of the live feed used in this study

${ }^{2}$ Other sources give values between $4 \%$ and $10 \%$ for Lumbricus rubellus fat content 
The distribution of the three treatments/five replicates across the 15 net compartments was fully randomised. Feeding was twice daily (0:600 and 18:00 local time, GMT+8), at 11\% of body weight. Each replicate (individual fish) was measured (total length, TL in $\mathrm{cm}$, precision $1 \mathrm{~mm}$ ) and weighed (in grams, precision $0.1 \mathrm{~g}$ ) weekly for a period of 8 weeks.

\section{Data Analysis}

Relative growth in weight was calculated as $\left(\mathrm{W}_{\mathrm{t}}-\mathrm{W}_{0}\right) \cdot \mathrm{W}_{0}^{-1}$, where $\mathrm{W}_{0}$ is the initial weight and $\mathrm{W}_{\mathrm{t}}$ is the weight at time t. Relative growth data for the three treatments and were statistically analysed (compared) using a one-way analysis of variance (ANOVA). The difference between treatments was considered statistically significant if $\mathrm{F}>\mathrm{F}_{\text {crit }, \alpha=0.5}(\approx 5.32)$. The quantitative and qualitative results were evaluated in the context of aquaculture development as well as snakehead biology and ecology.

The length-weight relationship $\mathrm{W}=a \mathrm{~L}^{b}$ describing the growth pattern of the juvenile snakeheads was calculated by merging all the weekly measurements for all the fish (3 stages, all treatments), with weight $\mathrm{W}$ in $\mathrm{g}$ and standard length SL in $\mathrm{mm}$. A linier regression was performed on the log-transformed data to yield the parameters $a$ and $b$. The resulting value of $b$ was compared with published data on $C$. striata length-weight relationships.

\section{Results}

Survival rate of the Channa striata juveniles was $100 \%$, and all specimens appeared to be in good condition throughout the study, though there was an increasingly visible variation in proportions as some individuals put on more weight (short/fat appearance) while others grew more in length (long/thin appearance). The initial weight, final weight and relative growth in weight (biomass) of the Channa striata juveniles over the 8-week study period are shown in Table 2. The results of the between-treatment ANOVA are shown in Table 3.

Table 2. Relative growth of $C$. striata juveniles under three feed treatments

\begin{tabular}{lcccccc}
\hline \multirow{2}{*}{ Treatment ${ }^{1}$} & \multicolumn{2}{c}{$\begin{array}{c}\text { Initial Weight } \\
\text { Average } \pm \text { SD } \\
(\mathrm{g})\end{array}$} & \multicolumn{2}{c}{$\begin{array}{c}\text { Final Weight } \\
\text { Average } \pm \text { SD } \\
(\mathrm{g})\end{array}$} & \multicolumn{2}{c}{$\begin{array}{c}\text { Relative Growth } \\
\text { Average } \pm \text { SD } \\
(\%)\end{array}$} \\
\hline A (golden apple snail) & 59.22 & 3.47 & 66.20 & 4.88 & $11.79 \%$ & $4.24 \%$ \\
B (Blue panchax) & 68.74 & 6.11 & 83.76 & 5.53 & $21.85 \%$ & $11.65 \%$ \\
C (Earthworms) & 61.72 & 9.90 & 67.60 & 9.79 & $9.53 \%$ & $2.23 \%$ \\
Total $(\mathrm{N}=15)$ & 63.23 & 7.72 & 72.52 & 10.53 & $14.70 \%$ & $8.87 \%$ \\
\hline
\end{tabular}

Table 3. ANOVA between treatments for relative growth $\left(\mathrm{F}_{\text {crit }, \alpha=0.5}=5.32\right)$

\begin{tabular}{ccccc}
\hline Treatment & & $\mathrm{A}$ & $\mathrm{B}$ & $\mathrm{C}$ \\
\hline & $\mathrm{A}$ & & $*$ & $\mathrm{~ns}$ \\
& $B$ & $\mathrm{~F}=6.78$ & & $*$ \\
& $\mathrm{C}$ & $\mathrm{F}=10.18$ & $\mathrm{~F}=0.80$ & \\
\hline
\end{tabular}

$*$ = significant ns $=$ not significant

Treatment B (blue panchax) produced the highest average relative weight gain of $21.85 \%$, significantly different from treatments A and C. All five fish grew steadily, however this treatment also exhibited the highest variation in relative growth, from $9.9 \%$ to $41.7 \%$. This variability is reflected in the standard deviation of $11.65 \%$.

Relative growth under treatments $\mathrm{A}$ and $\mathrm{C}$ was not significantly different, with respective averages of $11.79 \% \pm 4.24 \%$ and $9.53 \% \pm 2.23 \%$, both close to half the average for treatment $\mathrm{B}$. The juvenile snakeheads required a period of adaptation to these new feeds. Initial growth was slow, however growth rates increased towards the end of the study period. Variation in relative 
growth was less marked than for treatment B, in both absolute and relative terms, as reflected in the smaller standard deviations. Under these two treatments, the relative growth of most fish was close to $10 \%$, with one much faster growing specimen (19\%) in treatment A.

The log-transformed linear regression of the length-weight data is shown in Figure 1. This yielded a value for coefficient $a$ of $6.8 \cdot 10^{-6}$ and for $b$ of 3.05. With $\mathrm{b}=3$, the overall length-weight relationship is considered to be isometric. The results are compared with data from the two previous phases and from other studies in Table 4.

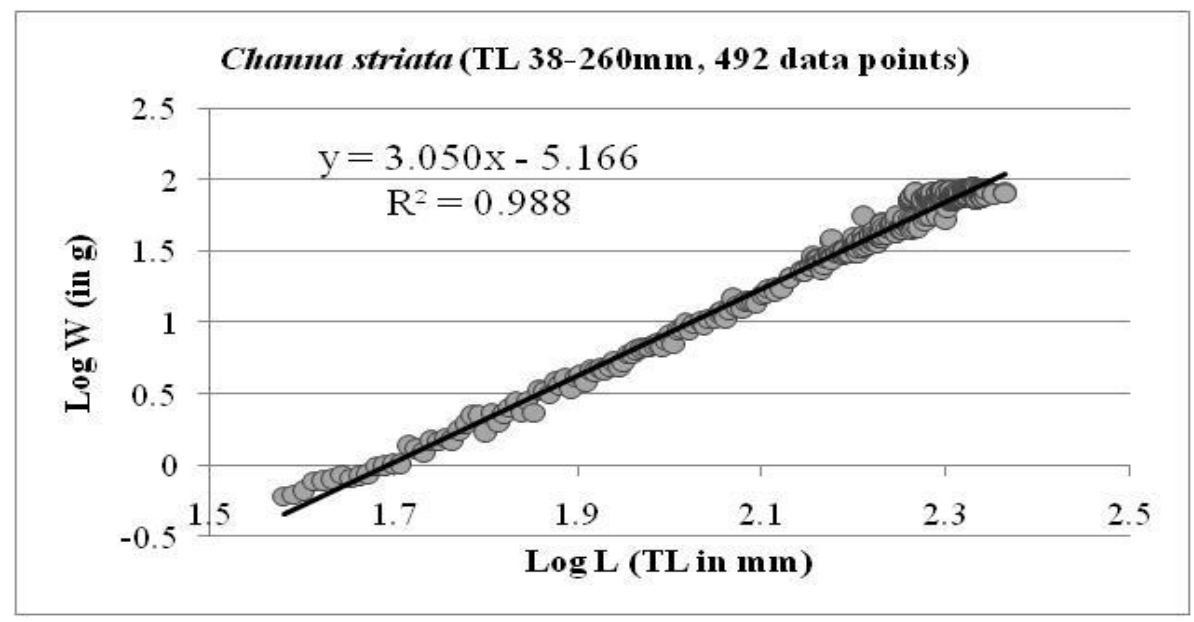

Figure 1. Regression of log-transformed length-weight data for juvenile C. striata showing isometric length-weight relationship $\mathrm{W}=a \mathrm{~L}^{b}$ with $b \approx 3$ and $a \approx 6.8 \cdot 10^{-6}$ for TL in $\mathrm{mm}$ and $\mathrm{W}$ in $\mathrm{g}$

Table 4. Comparison of observed length-weight relationship with published data on Channa striata

\begin{tabular}{llllll}
\hline TL range $(\mathrm{mm})$ & $\mathrm{n}$ & $\mathrm{b}( \pm \mathrm{SE})$ & $\mathrm{R}^{2}$ & $\begin{array}{l}\text { Growth } \\
\text { pattern }\end{array}$ & \multicolumn{1}{c}{ Source } \\
\hline $38-63$ & 90 & $2.62 \pm 0.11$ & 0.961 & AN & This research program (Ndobe et al., 2013) \\
$64-143$ & 31 & $2.99 \pm 0.06$ & 0.983 & $\mathrm{I}$ & \\
$100-200$ & $\mathbf{1 5 - 9 0}$ & $3.05 \pm 0.015$ & $\mathbf{0 . 9 8 8}$ & $\mathrm{I}$ & This paper \\
$\mathbf{3 8 - 2 3 1}$ & 13 & 2.99 & 0.982 & $\mathrm{I}$ & Li et al. (2013) \\
$106-393$ & 11 & 3.44 & 0.994 & AP & Beamish et al. (2010) \\
$35-257$ & 772 & $2.88 \pm 0.013$ & 0.99 & AN & Kumar et al. (2013) \\
$20-306$ & 297 & 3.2842 & - & AP & Amilhat (2006) \\
TAD & 451 & $2.94 \pm 0.22$ & 0.963 & AN/I & Satrawaha and Pilasamorn (2009) \\
$155-451$ & & & & & \\
& 50 & $2.77-3.12$ & $0.94-0.98$ & AN/I & Makmur (2003) \\
82-459 & 100 & $3.89-4.11$ & 0.806 & AP & Dayal et al. (2012) \\
$35-45$ & 37 & 3.0 & 0.892 & I & \\
$109-254$ & 89 & $3.41-3.96$ & 0.933 & AP & \\
$229-424$ & & &
\end{tabular}

$\mathrm{TL}=$ total length (in $\mathrm{mm}$ ); - = no data; $\mathrm{n}=$ number of fish used in study; $\mathrm{SE}=$ standard error; $\mathrm{R} 2=$ regression correlation coefficient for $\log (\mathrm{W})=\log \mathrm{a}+\mathrm{b} \log (\mathrm{TL}$ in $\mathrm{cm}) ; \mathrm{AN}=$ allometric negative; $\mathrm{AP}=$ allometric positive; $\mathrm{I}=$ isometric 


\section{Discussion}

The higher relative growth of the juvenile snakeheads fed on blue panchax (Treatment B) confirms and expands the results of Serdiati et al. (2013), showing that Aplocheilus panchax is not only suitable as a feed for small juvenile striped snakeheads, but can be continued for large juveniles approaching the adult stage. Given the ease with which this live feed can be caught from drainage channels and other areas at no cost other than the logistics of procuring (catching) them, this is important information for would-be fish-farmers in the Palu area and other areas where "kepala timah" are similarly abundant. Developing the culture of A. panchax separately or in polyculture as feed for $C$. striata may be one option for ongoing domestication of the striped snakehead.

During an initial adaptation period, the juvenile fish in treatments B and C exhibited some reluctance to eat the new feed offered, however by the middle of the trial period all feeds were accepted. In treatment A, initially only the soft parts of the golden apple snails were eaten, as the juvenile snakeheads were unable to bite or tear off flesh from the muscular foot or swallow the pieces provided whole. However after the snails were chopped into suitable sized pieces, and the fish had been hungry for a few days, they were readily consumed. This slow start may have influenced the trial results, and there was an increase in growth towards the end of the study period for this treatment. Treatment $\mathrm{C}$ showed that earthworms are palatable to juvenile snakeheads, and there was less delay in adaptation to this feed.

The differences in initial weight (a stochastic outcome of the random selection process) could account for some of the between treatment difference, bearing in mind the tendency of the snakehead juveniles study towards an isometric (cubic) growth pattern (Figure 1). It should also be noted that individual variability in behaviour and growth was high throughout the three research stages. The lower total and relative growth of the juvenile striped snakeheads fed on earthworms or golden apple snails compared to those fed on blue panchax could therefore be partly due to or magnified by the research conditions and the small sample size.

All three feed treatments were high in protein (Table 1), and should be suitable for $C$. striata as a carnivorous fish, which can consume a wide variety of prey in the wild including invertebrates as well as fish (Kumar et al., 2008). This view is supported by the fact that all the fish remained in good condition throughout the study period, and it is reasonable to conclude that blue panchax, earthworms and golden apple snails can be acceptable to striped snakehead juveniles and could be used in the culture of this species.

The observed between treatment differences in growth could also be influenced by differences in the nutritional quality or digestibility of the feeds. It is remarkable that despite having the largest range of initial and final weights, treatment $\mathrm{C}$ exhibited the smallest range of relative growth as well as the lowest average growth, a fact which points towards the possibility of nutritional deficiency. The levels of other nutrients, including micro-nutrients in earth worms and golden apple snails may be below optimum. Indeed the varied diet of $C$. striata in the wild would almost certainly comprise a wider range of nutrients that that found in any one single prey or feed item. The blue panchax is a carnivorous fish, with a diet which seems to be similar to that of snakehead fry. It is therefore likely that this fish provides a closer match to optimum striped snakehead dietary requirements, and we have observed that blue panchax can be a prey item for $C$. striata in the wild.

Fat content and fat/protein ratios are reported as significant factors for $C$. striata fry (Aliyu-Paiko et al., 2010), affecting not only growth and survival but also proximate body composition. Table 1 and other available data on the composition of earthworms and golden apple snails indicate that fat levels are lower than the laboratory results we obtained for blue panchax. This may indicate that lipid content and the lipid to protein ratio affect juvenile striped snakehead growth. If this is so, further research should enable the formulation of a range of mixed feeding plans to overcome this limitation.

Golden apple snails are a pest to rice-farmers, and using them as an aquaculture feed could therefore have an added advantage for the local community. Earthworms are not naturally abundant but can be readily cultivated through composting organic waste. Earthworm production could also 
have positive side-effects, reducing the severe waste problem now in evidence in both rural and urban areas. Both snails and worms could be used in developing mixed live/fresh feed formulations and in formulating pelleted feed, and they can be used as a temporary solution when feeds more susceptible to seasonal variations in availability are less abundant.

The isometric length-weight relationship provides a very close fit $\left(\mathrm{R}^{2}=0.988\right)$ over the study period as a whole. However deviation from this regressed isometric length-weight relationship was greatest for fry and for large (sub-adult) juveniles. At these life stages individual variance in body proportions and growth rate/patterns was greatest. In the wild, the majority of the fry would not survive, and this variability is likely related to retaining plasticity and various survival strategies. The high variability seen even in small samples such as in this study indicates the potential for selective breeding and improvement as part of the long-term domestication process.

As juvenile fish approach maturity, as with many other organisms, the onset of processes related to the development of sexual maturity may affect growth rate and condition factor. For example, early gonad development can readily occur in some freshwater species, especially in captivity, and can result in reduced growth rates or even stunted growth (Munro and Lam, 1993) or conversely sexual maturity may occur earlier in faster growing individuals, as suggested by Isangedighi and Umoumoh (2011). However there seems to be little information on this subject in respect of $C$. striata. The factors affecting the development of sexual maturity and the relationship between growth and sexual maturity as well as the respective roles of intrinsic (individual/inherited) characters and environmental parameters on growth in the striped snakehead at various life-stages are possible areas for future research.

\section{Conclusion}

The results of this study show that three readily available low-cost feeds can be used in the culture of juvenile striped snakeheads, and combined with two previous research stages, show that Channa striata fry can be reared to sub-adult size on readily available and low cost feeds. Further research at each life stage is still needed to determine optimum parameters for mixed live/fresh feed diets and to formulate viable artificial feed alternatives. Future directions for development include polyculture of $C$. striata with the prey fish A. panchax, the feed which produced the highest growth in this study. There are opportunities for developing feed formulations with added benefits through the use of a pest species $P$. canaliculata and waste recycling using $L$. rubellus.

There is still a long way to go in C. striata domestication, and although the support which enabled this study has ended, the authors intend to continue the program. Future research goals include ongoing feed development, full-cycle culture (breeding) and promoting community-level snakehead culture.

\section{Acknowledgements}

We would like to thank the Directorate General for Higher Education, Department of National Education for funding under the Competitive Research (Hibah Bersaing) scheme in 2013, under Letter of Agreement Ref. No. 68/P2IPT/DPPM/III/2004; the Institute for Fisheries and Marine Science (STPL) for the use of the pond and other facilities; Tadulako University Faculty of Animal Husbandry and Fisheries, all who took part in or assisted in this research especially Kamaluddin, Ummy Mahmuda, Deddy Wahyudi, Abdul Rahman, Arafik and Osmar Buatan, and the anonymous reviewers for their input towards improving this manuscript.

\section{References}

Aliyu-Paiko, M., R. Hashim and A.C. Shu-chien. 2010. Influence of dietary lipid/protein ratio on survival, growth, body indices and digestive lipase activity in Snakehead (Channa striatus, Bloch 1793) fry reared in re-circulating water system. Aquaculture nutrition, 16 (5): 466-474 
Amilhat, E. 2006. Fisheries Ecology of rice Farming Landscapes: Self-recruiting Species in Farmer Managed Aquatic Systems. Doctoral Thesis. Faculty of Science, University of London, UK. 184 pp.

Beamish, F.W.H., R. Plongsesthee, P. Chanintarapoomi and P. Nithirojpakdee. 2010. Total lengthweight relationships among Thai freshwater fishes and the influence of capture location and preservation. Journal of Applied Ichthyology, 27: 955-958. DOI: 10.1111/j.1439-0426.2010.01620.x

Dayal, R., P.P. Srivastava, A. Bhatnagar, S. Chowdhary, W.S. Lakra, S. Raizada and A.K. Yadav. 2012. Comparative Study of WLR of Channa striatus Fry-Fingerling, Grow-Outs and Adults of Gangetic Plains. Online Journal of Animal and Feed Research, 2 (2) : 174-176

Ebanasah, J. and V. Jayaphakas. 1994. Evaluation of Different Diets for the Cage Culture of Channa striatus. Journal of Inland Fisheries Society of India, 26 (1) : 59-66

Froese, R. and D. Pauly. 2013. http://www.fishbase.org/summary/Channa-striata.html. [Download 03/05/2013]

Hambrey, J., P. Edwards and B. Belton. 2008. An ecosystem approach to freshwater aquaculture: a global review. pp. 117-221 in Soto, D., J. Aguilar-Manjarrez and N. Hishamunda (Eds.). 2008. Building an ecosystem approach to aquaculture. FAO and Universitat de les Illes Balears Expert Workshop, 7 11 May 2007, Palma de Mallorca, Spain. FAO Fisheries and Aquaculture Proceedings. No. 14. FAO, Rome, Italy. 231p.

Isangedighi, I.A. and O.E. Umoumoh. 2011. Some aspects of the reproductive biology of African snakehead Parachanna obscura in Itu-Cross river system. Nigerian Journal of Agriculture, Food and Environment, 7(4): 19-30.

Istiqomah, L., A. Sofyan, E. Damayanti and H. Julendra. 2009. Amino Acid Profile of Earthworm and Earthworm Meal (Lumbricus rubellus) for Animal Feedstuff. Journal of Indonesian Tropical Animal Agriculture, 34 (4) : 253-257.

Keservani, R.K., R.K. Kesharwani, N. Vyas, S. Jain, R. Raghuvanshi and A.K. Sharma. 2010. Nutraceutical and functional food as future food: A review. Der Pharmacia Lettre, 2 (1) : 106-116

Kumar, K., P.L. Lalrinsanga, M. Sahoo, U.L. Mohanty, R. Kumar and A.K. Sahu. 2013. Length-weight Relationship and Condition Factor of Anabas testudineus and Channa Species under Different Culture Systems. World Journal of Fish and Marine Sciences, 5 (1) : 74-78. DOI: 10.5829/idosi.wjfms. 2013.05.01.64201

Kumar, D., K. Marimuthu, M.A. Haniffa and T.A. Sethuramalingam. 2008. Effect of Different Live Feed on Growth and Survival of Striped Murrel Channa striatus larvae. E.U. Journal of Fisheries and Aquatic Sciences, 25(2): 105-110

Laila, L., F. Febriyenti, S.M. Salhimi and S. Baie. 2011. Wound healing effect of Haruan (Channa striatus) spray. International Wound Journal, 8: 484-491

Li, Q., R. Xu and J. Huang. 2013. Length-weight relations for 20 fish species from the Pearl River, China. Acta Ichthyologica et Piscatoria, 43(1): 65-69

Liao, I.C. and Y.S Huang. 2000. Methodological approach used for the domestication of potential candidates for aquaculture. Recent advances in Mediterranean aquaculture finfish species diversification. CIHEAM. Cahiers Options Méditerranéennes, 47: 97-107

Makmur, S. 2003. Biologi Reproduksi, Makanan dan Petumbuhan Ikan Gabus (Channa striata Bloch) di Daerah Banjiran Sungai Musi Sumatera Selatan. Thesis. Bogor Agricultural Institute, Bogor, Indonesia. $72 \mathrm{pp}$.

Munro, A.D. and T.J. Lam. 1993. Control of gonad growth, maturation and spawning in teleost Fish: A review. pp. 1-53 in: Marte C.L., G.F. Quinitio and A.C. Emata (Eds.). Proceedings of the SeminarWorkshop on Breeding and Seed Production of Cultured Finfishes in the Philippines. 4-5 May 1993, Tigbauan, Iloilo, Philippines. SEAFDEC Aquaculture Department. [Available from http://repository.seafdec.org.ph/bitstream/handle/ 10862/564/bspcfp_p001-053.pdf?sequence=1]

Mustafa, A., M.A. Widodo and Y. Kristianto. 2012. Albumin And Zinc Content Of Snakehead Fish (Channa striata) Extract And Its Role In Health. International Journal of Science and Technology, 1(2): $1-8$

Ndobe, S., N. Serdiati and A. Moore. 2013. Upaya Domestikasi Melalui Pembesaran Ikan Gabus (Channa striata) di Dalam Wadah Terkontrol. Proceedings of the National Aquaculture Conference, 3-4 September 2013, Solo, Indonesia. pp. 165-175

Sarowar, M.N., M.Z.H. Jewel, M.A. Sayeed and M.F.A. Mollah. 2010. Impacts of different diets on growth and survival of Channa striatus fry. International Journal of Biological Research, 1(3): 0812

Satrawaha, R. and C. Pilasamorn. 2009. Length-weight and length-length relationships of fish species from the Chi River, northeastern Thailand. Journal of Applied Ichthyology, 2009: 1-2. DOI: 10.1111/j.1439-0426.2009.01293.x 
Serdiati, N., S. Ndobe and A. Moore. 2013. Growth of Juvenile Striped Snakehead (Channa striata) in a Controlled Environment with Live Feed (Aplocheilus panchax). Paper presented at the International Seminar on Maritime and Agribusiness, 13-14 December 2013, Tadulako University, Palu, Indonesia. In press

Shafri, M.M.A. and A.M.J. Manan. 2012. Therapeutic Potential of the Haruan (Channa striatus): From Food to Medicinal Uses. Malaysian Journal of Nutrition, 18 (1) : 125-136

Schneider, J.C., P.W. Laarman and H. Gowing. 2000. Length-weight relationships. Chapter 17 in J.C. Schneider (Ed.). 2000. Manual of fisheries survey methods II. Fisheries Special Report 25, Michigan Department of Natural Resources, Ann Arbor, U.S.A. 16 pp.

Srivastava, P.P., R. Dayal, S. Chowdhary, J.K. Jena, S. Raizada and P. Sharma. 2011. Rearing of fry to fingerling of saul (Channa Striatus) on artificial diets. Online Journal of Animal and Feed Research, 2(2): 155-161

Thongprajukaew, K., U. Kovitvadhi, S. Kovitvadhi, A. Engkagul and K. Rungruangsak-Torrissen. 2013. Evaluation of growth performance and nutritional quality of diets using digestive enzyme markers and in vitro digestibility in Siamese fighting fish (Betta splendens Regan, 1910). African Journal of Biotechnology, 12 (14): 1689-1702 